To cite this article: T.Y. Wang \& Alexander C. Tan (2021): Balancing, bandwagoning or hedging: Taiwan's strategic choices in the era of a rising China, Political Science, DOI:

$10.1080 / 00323187.2021 .1967765$

\title{
Balancing, Bandwagoning or Hedging: \\ Taiwan's Strategic Choices in the Era of a Rising China
}

\author{
T.Y. Wang \\ Illinois State University \\ And \\ Alexander C. Tan \\ University of Canterbury
}

T.Y. Wang \& Alexander C. Tan (2021): Balancing, bandwagoning or hedging: Taiwan's strategic choices in the era of a rising China, Political Science, DOI: 10.1080/00323187.2021.1967765 


\section{Balancing, Bandwagoning or Hedging: Taiwan's Strategic Choices in the Era of a Rising China}

Early literature on international relations has largely focused on the behaviors of great powers, examining how they interact with each other as their power waxes and wanes. ${ }^{1}$ The end of the Cold War and the collapse of Soviet Union have led to the change of global power structure that allows a number of small states to play a more active role in world politics. The ensuing rise of China and the perceived decline of the United States have generated interesting questions: how do such small states as Taiwan behave when they are confronted by a rising and threatening power like China? What are their strategic choices? What are the determinants of their foreign policies?

These research questions have generated a body of literature and three possible strategic options have been identified for small states: balancing, bandwagoning and hedging. ${ }^{2}$ Though domestic politics has been noted as an important determinant, many of these studies have focused on systemic and structural factors (e.g., Kang, 2003; Koga, 2018; Kuik, 2008; Pempel, 2010). Little attention has been paid to domestic determinants of small states. Indeed, a state's strategic behavior cannot be assessed by its external security environment alone. Various domestic factors may act as "transmission belts" that shape policy outputs in response to international forces (Schweller, 2004: 164). As Haggard rightly pointed out, "[i]n the absence of information on actors' preferences..., we are unlikely to generate defensible expectations about state behavior..." (Haggard, 2003: 60, quoted in Kang, 2003/2004: 173).

Domestic politics plays a central role in Taiwan's strategic responses to a rising China. Contrary to the observation that few citizens have the interest or the ability to comprehend the subtle meaning of foreign policies (Almond, 1950), empirical analysis has shown that the island country is a countervailing case (Wang, 2017). Taiwan citizens are very attentive to their country's relationship with China and hold strong opinions about it. As cross-Strait relationship plays a central role in the island's politics, "[i]t structures foreign policy; it structures the political party system; it structures much of how ordinary citizens orient themselves to politics" (Achen and Wang, 2017: 2). Thus, it is imperative to understand Taiwan citizens' preferences on Taipei's strategic choices.

This study is divided into several sections. In the next section, it examines the international relations literature on alliance behavior with a focus on the aforementioned strategic choices. A brief overview of cross-Strait relations is then conducted that sets the tone for the policy options of Taiwan's government and people. Employing survey data collected during the past two decades, the island citizens' view of cross-Strait relations and Taipei's strategic choices are identified in the following section. The data show that Taiwan citizens risk-averse attitude supports a hedging strategy but recent events in Hong Kong and the Trump administration's policies have contributed

${ }^{1}$ The most notable example is Waltz's comment that " $[\mathrm{t}]$ he theory, like the story, of international politics is written in terms of the great powers of an era.... In international politics, as in any selfhelp system, the units of greatest capability set the scene of actions for others as well as for themselves" (1975: 72).

${ }^{2}$ Other strategic options have also been identified, including hiding, transcending (Schroeder, 1994), buck-passing (Posen, 1984), nonalignment (Labs, 1992). 
to a shift in this policy preference which is mirrored in the government's approach toward China. As Beijing is expected to continue its assertive stand and the new Biden administration appears to take a hardline approach toward China, the final section concludes that Taipei's cross-Strait policy is likely to have a stronger balancing component.

\section{Strategic Options of Small States}

The Realist perspective maintains that the international system is inherently anarchical and national security is a state's paramount concern. The structure of power plays a major role in state interactions, which determines the "winners" and "losers" in the international arena. All sources of power, military or economic, are not readily usable and have to be subsumed to the issue of national security. In this self-help system, small states are placed in a relatively disadvantageous position. Great powers may provide help to small states with needed resources, but they can also threaten the security of small states for resources or political domination. Two broad approaches to state leaders have thus been prescribed when they are confronted by a strong and potentially threatening power. The first option is a balancing strategy involving either internal military build-up and/or forming an external alliance (Williams, Lobell, and Jesse 2012). The goal of this strategic move is to ensure autonomy and security in opposition to the menacing state. Alternatively, small states can choose a bandwagoning strategy, crouching under the rising power by conforming or not contradicting the latter's will and interests. By allying with the threatening state, the bandwagoner expects to avoid bringing harm to itself and sometimes to gain profits (Walt, 1985: 8). Several prominent international theorists suggest that balancing is more prevalent than bandwagoning in world politics. For instance, Waltz maintains that, in times of global power shift, small states "flock to the weaker side, for it is the stronger side that threatens them" (1979: 127). Similarly, Walt suggests that "states facing an external threat overwhelmingly prefer to balance against the threat rather than bandwagon with it" (1985: 15). The tendency of balancing is particularly strong if a rising power's aggregate capability is accompanied by geographical proximity, offensive capability and aggressive intention. As autonomy and security are on the line, balancing through an alliance provides more freedom of action than subjecting itself to the mercy of a potentially threatening power.

The above Realist perspective has faced strong criticism as recent scholarship challenges its description of Asian states' strategic responses to a rising China. It is pointed out that many countries in the region have military links with Western powers but they also develop close economic relationship and maintain diplomatic ties with China (Chan, 2010; Kang, 2003/2004; Koga, 2018; Kuik, 2008; Tan, 2012). None of these efforts constitutes a pure form of balancing or bandwagoning strategy. Instead, they have taken a third strategy: hedging.

Indeed, each of the two policy options, balancing or bandwagoning, has varying degree of costs and uncertain consequences. Internal balancing, for instance, involves a redistribution of internal resources that may be needed elsewhere, while external balancing encompasses the danger of "entrapment" and "abandonment." Similarly, a bandwagoner may lose its freedom of action due to a stronger state's political domination (Snyder 1984, 465-67; Koga, 2018; Kuik, 2008). In this context, hedging is a mixed strategic choice that intends to reduce the risks and costs associated with each individual option. Although multiple definitions have been offered in the literature (Goh, 
2006; Koga, 2018; Kuik, 2008; Roy, 2005), hedging is generally conceptualized as a hybrid strategy of combining both balancing and bandwagoning by which a country counters the threatening power through strengthening its own defense and/or forming an alliance with other countries while at the same time engaging with the menacing state. The bandwagoning strategy aims to enhance a friendly diplomatic relationship with the threatening power and generate economic and other benefits. The balancing act provides security guarantee in case the engagement approach fails or the threatening power becomes aggressive. Generally, the former happens in the economic field while the latter occurs in the security realm (Wu, 2017).

Thus, confronted by a rising and threating power, there are three strategic choices for small states: bandwagoning, balancing, and hedging. With this theoretical understand as a backdrop, the next section examines the evolution of cross-Strait relations that provides a picture of how these strategic options have played out in Taiwan.

\section{Cross-Strait Relations}

Since China and Taiwan was divided in 1949, Beijing leaders have considered "Taiwan's return to the motherland" as an important step toward national rejuvenation and have acted aggressively to further that goal. Several major battles were fought in the 1950s and 1960s and, with the help from the U.S., Taipei thwarted Communist military attacks on offshore islands held by Taiwan. Following the establishment of diplomatic relations between China and the U.S. in 1972, Chinese leaders changed their unification strategy from the "military liberation" of Taiwan to a wave of "peaceful initiatives." To entice Taipei into acceptance of its unification formula known as "one country, two systems," Beijing has isolated Taiwan internationally and backed up its claim with the threat of military force. Since late 1980s, Chinese leaders have further used its newly acquired economic clout to expand cross-Strait exchanges in an attempt to integrate Taiwan with the mainland. As a result, trade and investments between the two sides of the Taiwan Strait have increased substantially. China is now Taiwan's top trading partner and the principal destination of the island country's investors (MAC, 2020).

Meanwhile, Taiwan was experiencing rapid democratization as China elevated itself to a major power status in the international community. With robust electoral competition, political power is no longer a monopoly of a single party with peaceful alternation of power becoming a norm. The long-ruling, formerly authoritarian Nationalist Party (Kuomintang, or KMT) lost at the polls in 2000 and handed over power peacefully to the independence-leaning Democratic Progressive Party (DPP), only to return in 2008 in an equally peaceful transition and then lost its ruling power again in 2016. The rapid democratization has been accompanied by substantial identity change among Taiwan citizens. The fierce contestation between Chinese identity and Taiwanese identity, involving the interpretation of the relationship between Taiwan and the Chinese mainland, has become the most important political cleavage. Because the two main parties on the island take opposite sides on this fundamental divide, partisanship embodies the same division and forms two major political camps: the pan-Blue coalition led by the KMT and the pan-Green coalition led by the DPP. While pan-Blue supporters espouse "Chinese" as a part of their identity, pan-Green followers largely see themselves as "Taiwanese" (Wang, 2017) 
It is within this context that Taipei's strategy during the past two decades has been largely alternating between an emphasis on balancing and a stress on hedging toward an increasingly powerful China, depending on which political party is in power. During the eight-year presidency of Chen Shui-bian began in 2000, the Taipei government adopted an approach that leaned toward a balancing strategy. Chen has a strong pro-independence credential and his affiliated DPP is the only major political party on the island that has a plank of pursuing Taiwan's de jure independence. In addition to continuing to strengthen Taiwan's defensive capability to fend off China's military threats, the Chen administration rejected the "one China with different interpretations," dubbed as the "1992 Consensus," that Beijing leaders consider inviolable. The Consensus is an "agree-todisagree" verbal understanding presumably reached between Beijing and Taipei that allows them to interpret what "one China" means in their own ways (Su and Cheng, 2002). Taipei's DPP government also adopted a series of policies that were perceived as provocative, including holding referenda during the 2004 and 2008 presidential elections and making bids for regular membership in the United Nations (UN) and World Health Organization (WHO). Beijing has deemed these efforts as pretexts to declaring the island's de jure independence.

Although there were no military conflicts between China and Taiwan during Chen's eightyear presidency, the relationship between Taipei and Beijing was tense. When Ma Ying-jeou of the KMT won the 2008 presidential election, he vowed to improve cross-Strait relations by adopting a policy of rapprochement towards China. In sharp contrast to his predecessor, Ma embraced the "1992 Consensus" (Ma, 2008). Because the "agree-to-disagree" formula honored the notion of "one China" but allowed both sides to interpret what it meant in their own way, it set aside Taiwan's sovereignty issue which was, and still is, the "contact killer" of cross-Strait relationship. By accepting the notion of one China, along with his proclamation of the Three-no policy, "no unification, no independence, and no use of military force," Ma essentially reversed the pro-independence policies of his predecessor. The Ma administration's rapprochement was welcome by Beijing. As tension across the Taiwan Strait attenuated, economic and people-topeople exchanges between the island and the Chinese mainland flourished as a result. A series of cross-Strait agreements were reached, including accords on scheduled direct flights, direct cargo shipping, tourism, Chinese investment in Taiwan, financial cooperation, intellectual property right, and the safety of Chinese food products as well as a landmark Free Trade Agreement (FTA)-like deal - the Economic Cooperation Framework Agreement (ECFA). Meanwhile, because Ma's policies substantially reduced cross-Strait tension, it was praised by the Bush administration and thus also improved the strained Taiwan-U.S. relationship during the tenure of Ma's predecessor (Rigger, 2009). Taipei's policy toward China between 2008 and 2016 thus has a stronger component of a hedging strategy, exemplified "by a cross-Strait rapprochement and intensified economic integration" (Wu, 2017: 208).

The pendulum of cross-Strait relations swung to the other end again after President Tsai Ing-wen's landslide victory in Taiwan's 2016 election. Like others who are pro-independence, Tsai has been alarmed by the rapid expansion of cross-Strait economic exchanges, which, in her mind, would increase the island's economic dependence on the mainland market and exposed its vulnerability (Tsai, 2009). She also considers the 1992 Consensus unacceptable because it implies Taiwan is a part of China and constitutes an infringement to the country's sovereignty and autonomy. The Tsai administration thus has refused to endorse the Consensus and has actively pursued the New Southbound Policy aiming to leverage Taiwan's cultural, economic, educational 
and other assets and expand ties with countries of ASEAN and states in South Asia, including Australia, and New Zealand (Glaser, Kennedy, Mitchell with Funaiole, 2018).

In a major policy address commemorating the $40^{\text {th }}$ anniversary of the "Message to Taiwan Compatriots," Chinee President Xi Jinping explicitly equated Beijing's one China with the 1992 Consensus, seemingly giving no room for different interpretations of what one China means. He also indicated that the "one country, two systems" unification plan, currently implemented in Hong Kong and Macau, would be the only viable option for Taiwan. While he pledged that Beijing's effort of unification would be peaceful, he also emphasized that "we make no promise to renounce the use of force and reserve the option of taking all necessary means" (Xi, 2019). Tapping into Taiwan citizens' anxiety over Xi's address, Tsai immediately issued a statement that firmly rejected Beijing's overture: "we have never accepted the 1992 Consensus" and "Taiwan absolutely will not accept one country, two systems" (Office of the President, 2019).

In this context, Beijing has applied various diplomatic and economic measures on Taipei since 2016 to pressure Tsai to return to the Consensus and accept the notion of one China. These measures include suspending all official communications with Taipei and drastically reducing the number of mainland tourists visiting Taiwan to hurt its tourist industry. The Chinese government has further launched a concerted effort to place diplomatic pressure by luring Taiwan's few remaining diplomatic allies away. Seven countries switched diplomatic recognition from Taipei to Beijing during Tsai's first term as the president, leaving only 15 nations that officially recognize Taiwan. $^{3}$ Due to Beijing's objection, Taipei was also excluded from the International Civil Aviation Organization and the World Health Assembly (WHA) meetings. China further repeatedly sent military aircraft and ships to circle the island aiming to intimidate the Taipei government and its citizens.

As Beijing intensified its military activities near Taiwan, the Tsai administration has actively engaged in internal military build-up. To boost its defensive capability, Taipei acquired or is in the process of acquiring large quantity of advanced weaponry from the U.S. to boost its defensive capability, including anti-ship missiles, underwater mines, and armed drones and related equipment (Brunnstrom, Zengerle, Stone, 2020; Girard, 2020; Lee, 2020). In part due to the antiChina sentiment permeated in the U.S., Taipei has been able to foster a much closer relationship with Washington. Tsai first engaged in a congratulatory phone call with then President-elect Donald Trump in 2016, breaking almost 40-year diplomatic protocol. As Washington-Beijing relations deteriorated during the Trump presidency, especially since the start of the U.S.-China trade dispute in 2018, Washington has taken a series of policies toward Taiwan that angered Beijing leaders but inspired the island citizens, including dispatching a cabinet-level official and a high-ranking military officer to visit Taipei, supporting Taiwan's application for a regular membership in the WHO, as well as, as noted, authorizing sales of advanced weaponry to Taiwan - some of these weapon systems having offensive capability (Girard, 2020). Observers in the U.S. openly called for replacing American's policy of Strategic Ambiguity with a policy of Strategic Clarity (Bosco, 2020; Haass and Sacks, 2020), explicitly indicating that Washington will defend

3 These seven countries are: Sao Tome and Principle (December 2016), Panama (June 2017), Dominican Republic (May 2018), Burkina Faso (May 2018), El Salvador (August 2018), the Solomon Islands (September 2019) and Kiribati (September 2019). 
Taiwan in the event that Beijing launches a military attack at the island country. The internal military build-up and allying with the U.S. show that the Tsai administration is increasingly moving toward the strategy of balancing.

Thus, Taipei's cross-Strait policy has been alternating between balancing and hedging during the past two decades, depending on which political party is in power. Because power transition in Taiwan is largely determined at the ballot boxes, it is important to explore Taiwan citizens' policy preferences on the island's relations with China. The next section will turn to this task.

\section{Taiwan Citizens' Policy Preferences}

To examine Taiwan citizens' policy preferences on cross-Strait relations, the following analysis will examine the data from the Taiwan National Security Survey (TNSS). The TNSS consists of multi-year nationwide surveys sponsored by the Program in Asian Security Studies of Duke University.

As noted, confronted by a rising and assertive China, Taiwan has three strategic choices: bandwagoning, balancing and hedging. The bandwagoning strategy is to conform or not contradict Beijing's will and interests. For this strategic choice, it means that Taipei would accept the "one country, two systems" unification framework or agree on an arrangement that is largely dictated by Chinese leaders. Essentially, Taiwan would be unified with China with Beijing being the central government and the island being a local special administrative region like Hong Kong and Macau. Under Beijing's current plan, the Chinese mainland would continue the practices of communism/socialism while the island retain its capitalist system and enjoy a high degree of autonomy. For nearly three decades, Beijing leaders have not changed their offer to Taipei (State Council, 1993; TAO, 2000). Chinese President Xi repeated these messages in his January 2019 speech. He stressed that Beijing's proposal would fully guarantee Taiwan citizens' "private property, religious beliefs and legitimate rights and interests" and respect Taiwan citizens" "life style and social system" (Xi, 2019).

Taiwan citizens have always been skeptical about Beijing's offer despite the island's close economic ties with China. In a survey conducted in 2002, approximately 50 percent of the respondents consider Beijing's unification plan unacceptable even if the plan promised to keep Taiwan unchanged for 50 years. As Figure 1 shows, more than two-thirds of the respondents opposed the plan when details of limits on Taiwan are considered. These limitations include: i) rights of judicial adjudication, ii) ability to acquire arms from foreign countries, iii) ability to conduct foreign affairs, and iv) rights of freely electing public officials. All of these limitations have been imposed onto Hong Kong in one form or another since 1997 (Wang and Liu, 2004).

Taiwan citizens' skepticism about Beijing's offer continues to this day. When being presented with Xi's recent assurance that the life in Taiwan would remain unchanged under the "one country, two systems" plan, more than $60 \%$ of the citizens show little confidence in the pledge, as Figure 2 shows. The consistent disapproval of Beijing's proposal explains why the Taipei government - regardless of the political party in power - never seriously consider bandwagoning as 
a politically palatable strategy.

Alternatively, a balancing strategy would require Taiwan to form an external alliance and/or take a forceful military posture. When asked if they would support forming an alliance with the U.S. and Japan to confront China, Figure 3 demonstrates that Taiwan citizens have increasingly supported this proposition. The data show that a slight majority disapproved such a confrontational approach in 2016 but the public was split on the issue in 2019. Their support became stronger in 2020 as more than $50 \%$ of the respondents now support forming an external alliance to confront an aggressive China. Further, roughly $65 \%$ of Taiwan citizens have consistently displayed a preference on taking moderate measures to handle cross-Strait disputes, as Figure 4 shows. In the most recent survey conducted in 2020, however, the support for a moderate response declined by $15 \%$ while their support for a forceful measure increased by almost equal percentage points. Thus, both figures show that a substantial proportion of Taiwan citizens have now shifted their position toward a balancing strategy even though a sizable population on the island continues to support a more moderate approach.

There are two possible explanations for this change of attitude. The first one is related to the recent development in Hong Kong. Since the 1997 handover, the former British colony has become a special administrative region of China. Under the "one country, two systems" framework, Hong Kong "shall enjoy a high degree of autonomy" (Article 12, Basic Law of HKSAR) and "the previous capitalist system and way of life shall remain unchanged for 50 years" (Article 5, Basic Law of HKSAR). ${ }^{4}$ Critiques, however, have pointed out that the Beijing government has undercut such a commitment since 1997 (e.g., Hui, 2017). Hong Kong people's rallies in support of democracy in recent years, Beijing's subsequent forceful responses, and the promulgation of a restrictive national security law for Hong Kong in 2020 have caused great concern amongst Taiwan citizens. When asked if these events would further their support for Taiwan independence, Figure 5 shows that $90 \%$ of the independence-leaning respondents are now more determined to pursue the island's permanent separation from China, while $40 \%$ of status-quo-leaning citizens are also more supportive of Taiwan independence. Even $20 \%$ of those who prefer the island's eventual unification with the Chinese mainland have changed their minds. Furthermore, more than $70 \%$ and $50 \%$ of the concerned citizens, respectively, are supportive of forming an external alliance and/or taking a forceful military posture to confront China's aggression. Clearly, the continuing erosion of Hong Kong people's rights and freedoms has heightened the public's fear of political integration with the Chinese mainland and significantly hardened their resistance to Beijing's unification efforts. For many island citizens, "today's Hong Kong" would be "tomorrow's Taiwan" if they do not resist (Wu, Yim, Chang and Cao, 2020).

The Trump administration's support for Taiwan may provide the second possible explanation as the friendly Taipei-Washington relationship has boosted the public's confidence that the U.S. will come to Taiwan's aid should China launch a military attack. Indeed, Washington's policy of strategic ambiguity - making it clear that "any effort to determine the future of Taiwan by other than peaceful means, including boycotts or embargoes" would be of "grave concern" to the US (Taiwan Relations Act, Section 2 (a)), but refusing to spell out exactly what would

${ }^{4}$ See, the Basic Law of the Hong Kong Special Administrative Region of the People's Republic of China, at <https://www.fmprc.gov.cn/mfa_eng/ljzg_665465/3566_665531/t23031.shtml >, accessed November 24, 2020. 
trigger an American military response - is a form of deterrence (Chan, 2003; Christensen, 2002). By keeping its military options ambiguous, Washington has been able to deter Beijing from using nonpeaceful means to achieve China's unification with Taiwan. Figure 7 presents the public's responses in two scenarios: 1) Beijing launches a military attack at the island when Taipei has no provocation; and 2) Beijing's military attack was a response to Taipei's declaration of independence. In the first scenario, about $65 \%$ of the respondents believe that the U.S. will come to Taiwan's aid, while more than $50 \%$ of the public continues to have confidence in American's help in the second scenario. Such a high level of confidence may also explain why Taiwan citizens are willing to take a more forceful position against Beijing's inimical behavior. As Figure 8 demonstrates, about $70 \%$ and $50 \%$ of the confident citizens in the first scenario, respectively, are supportive of forming an external alliance and/or taking a forceful military posture against Beijing's inimical behavior. An even slightly higher proportion of the public in the second scenario are supportive of such a balancing strategy (not shown to avoid repetition).

That said, there is a substantial number of the public supporting the hedging policy adopted by former President Ma, embodied in his endorsement of the 1992 Consensus and the expansion of cross-Strait economic exchanges. The public's backing for a hedging policy started before Ma's presidency, which has consistently received the majority support since 2005, as Figure 9 demonstrates. However, the Consensus' favorability has declined by $10 \%$ in 2020 while its opposition has increased by about the same percentage. This is also likely attributable to Beijing's repressive responses to the pro-democracy movement in Hong Kong that consequently raised alarm among Taiwanese citizens.

Along with the declining support for the 1992 Consensus comes with increasing opposition to expanding cross-Strait interactions, as Figure 10 shows. Between 2004 and January 2019, the public's support for economic exchanges between Taiwan and China fluctuates as it trended higher during the independence-leaning Chen administration (2000-2008) when restrictive measures were imposed. The support level trended downward when economic interactions experienced rapid expansion during the China-friendly Ma administration (2008-2016). The fluctuation shows Taiwan citizens' ambivalence about cross-Strait economic exchanges. On the one hand, the public appears to appreciate the resulting economic benefits. On the other hand, they also recognize the potential danger associated with the deepening economic dependence that may expose the island country's vulnerability. Probably due to Beijing's increased hostility towards Taipei since the election of Tsai as Taiwan's president, the support for expanding cross-Strait exchanges has declined substantially since 2017 .

Overall, survey data collected on the island during the past 20 years show that Taiwan citizens generally are in favor of a hedging policy. While the majority of Taiwan citizens are not willing to submit to Beijing's "one country, two systems" unification plan, they also do not want to be overly confrontational by actively pursuing the island's de jure independence and thereby inviting a violent response from Chinese leaders. However, Beijing's hostile actions toward the Tsai administration and its repressive responses to Hong Kong residents' quest for democracy and freedom have alarmed Taiwan citizens. While not forgoing the engagement approach, the policy preference of the public in recent years seems to tilt toward the side of balancing against a threatening China. This change in the public's preference now seems to be mirrored within the Tsai administration as evidenced by the recently published interview of Joseph Wu, Taiwan's 
Minister of Foreign Affairs, with a UK newspaper, the Guardian. In that interview, Wu called for the international community to join together with Taiwan to resist China's expansionism (Davidson, 2020).

\section{Conclusion}

This study asks at the outset how small states behave when confronted by rising and threatening powers and how their foreign policies are determined. Despite the asymmetry in power and size, the extant literature informs us that small states are not without options to ensure their own national security and survival. Small states, according to the literature, have throughout history chosen to bandwagon, to hedge, or to balance against an inimical power. Taiwan, as a small state, is no exception. Confronted by a rising, strong, and threatening China, the island country has been observed to behave like other small states when facing a similar conundrum. The analysis of survey data collected in Taiwan during the past two decades shows that citizens' policy preferences are relevant factors to the government's strategic choices. While the precise causal relationships are not easily sorted out and would require a more stringent 'test,' the data demonstrate that the association between Taipei's cross-Straits policy and public opinion is clear and evident.

In general, the island citizens are risk averse. Collectively, they are sensitive to the benefits and costs associated with each of the available strategic choices. Because unification under Beijing's terms would necessarily sacrifice their hard-won democratic freedoms, Taiwan citizens have overwhelmingly rejected Beijing's "one country, two systems" proposal. Without the public's support, the democratically elected government has never considered bandwagoning as a politically plausible and acceptable strategy. Similarly, a "pure" balancing strategy that was adopted between 1950s and 1970s is also unpalatable due to the enormous costs and associated risks. Instead, the island citizens are generally supportive of setting aside the sovereignty dispute with a rapprochement approach toward China. Hedging thus becomes a preferred strategic option for most, if not all, Taiwan citizens.

The recent precipitous decline of the public's support for the 1992 Consensus and crossStrait economic exchanges is telling. While Chinese leaders' overture seems accommodating, its message, embodied in Xi's 2019 address, is threatening and inflexible, indicating to Taiwan citizens that unification can only come under Beijing's terms and that military force will be used if necessary. This perceived hardline attitude coupled with China's restrictive new security law that curtails the rights and freedom of the Hong Kong people has set off alarms in Taiwan, further eroded the credibility of Beijing's assurances to the island citizens and hardened their resolve to resist. Together with more explicit support of Taiwan under the Trump administration, the public's policy preference seems to be tilting towards balancing against a China that is perceived increasingly aggressive. Taiwan citizens' shift in policy preferences now seems to be echoed by the Tsai administration's call for like-minded countries to stand together with Taiwan in the face of China's aggressive behavior.

The future dynamics of public opinion and Taipei's strategic choices will continue to be influenced by Beijing's conduct and America's policy toward China and Taiwan, barring 
unforeseen circumstances. China has become increasingly assertive in its behavior, particularly under Xi's leadership. Externally, Beijing has been expanding its control of the South China Sea, pushing against the border between China and India, increasing its economic and diplomatic influence across the globe and mounting military threat against neighboring countries like Taiwan and Vietnam. Internally, in defiance of international opinion, Chinese leaders have widely applied mass surveillance through artificial intelligence technology on their own citizens, built concentration camps in Xinjiang, and continued repressive measures on Hong Kong. While Xi in his congratulatory message to President-elect Joe Biden that he hoped the future U.S.-China relationship would be based on "the spirit of non-conflict, non-confrontation, mutual respect and win-win cooperation" (Jiang, Duster and Gaouette, 2020), the perceived decline of American international status and the chaotic Trump administration appeared to embolden Chinese leaders to continue their aggressive policies, including the forceful approach toward Taiwan.

Meanwhile, the Biden administration has followed the Trump administration to break away from the Obama administration's engagement-focused approach toward China. In a recently published op-ed, Biden argued that "the United States does need to get tough with China" by "building a united front of U.S. allies and partners to confront China's abusive behaviors and human rights violations, even as we seek to cooperate with Beijing on issues where our interests converge..." (Biden, 2020). Although Taiwan was not mentioned, Biden has previously maintained that "the United States has a vital interest in helping Taiwan sustain its vibrant democracy" and he is committed "to preserving Taiwan's autonomy" (Biden, 2001). This line of strategic thinking is reflected in the selection of his national security team. In a pair of co-authored essays, Jake Sullivan, Biden's national security adviser, argues that "there is a growing consensus that the era of engagement with China has come to an unceremonious close" and China is considered a "challenging competitor" (Campbell and Sullivan, 2019). To be a "dominant player in the Western Pacific," Beijing is expected to be "out to the first island chain (which runs from Japan to Taiwan to the Philippines) and beyond" (Brands and Sullivan, 2020). Taiwan is thus important for Washington not only for its vibrant democracy but also for its strategic position in U.S.-China competition for global leadership. Since taking office, Biden has continued to strengthen America's support for the island country, including dispatching an unofficial delegation to Taipei to send a "personal signal" of the president's commitment to Taiwan's security and democracy (Brunnstrom and Martina, 2021).

Beijing is likely to respond very strongly if it believes that Taipei's balancing approach, inspired and supported by the U.S., will lead to Taiwan's permanent separation from China. Chinese leaders have always suspected that Washington has a hidden agenda to undermine their cause of unification. America's support for Taiwan is precisely the action that may be interpreted as confirming such a covert U.S. policy. It is thus incumbent on Washington's convincing assurance to Beijing that its policy aims to protect Taiwan's vibrant democracy and the well-being of its people but does not support the island's de jure independence. This logic underscores Sullivan's comment that "a tacit commitment not to unilaterally alter the status quo [of Taiwan]" is the best course of action for the Taiwan issue (Campbell and Sullivan, 2019).

Overall, Taipei DPP government's strategic choice is likely to have a stronger balancing component due to Beijing's persistence of an assertive behavior and Washington's strengthening support. The cold and tense cross-Strait relationship since 2016 is expected to continue beyond 
the tenure of Taiwan's pro-independence incumbent government. 

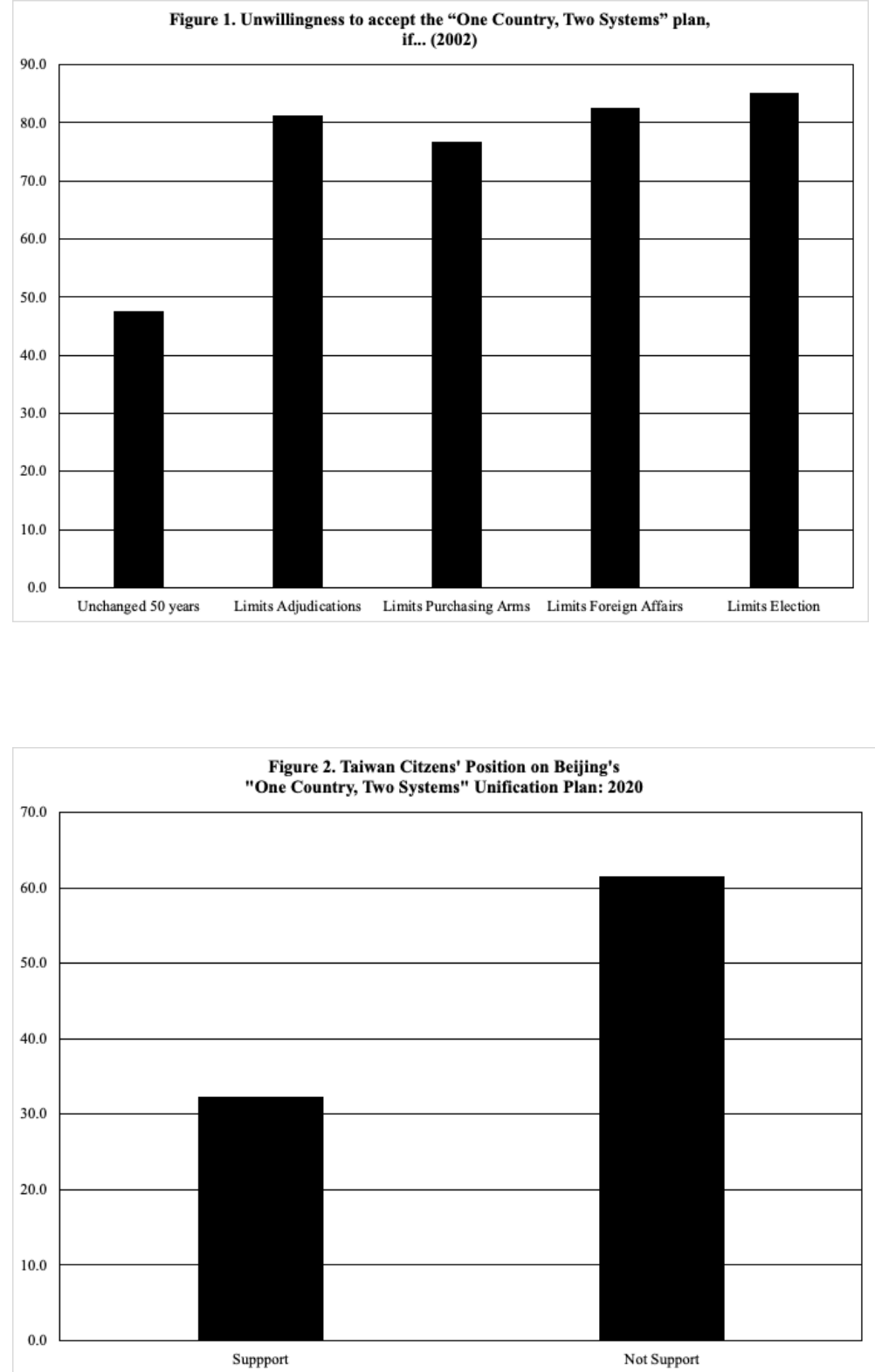

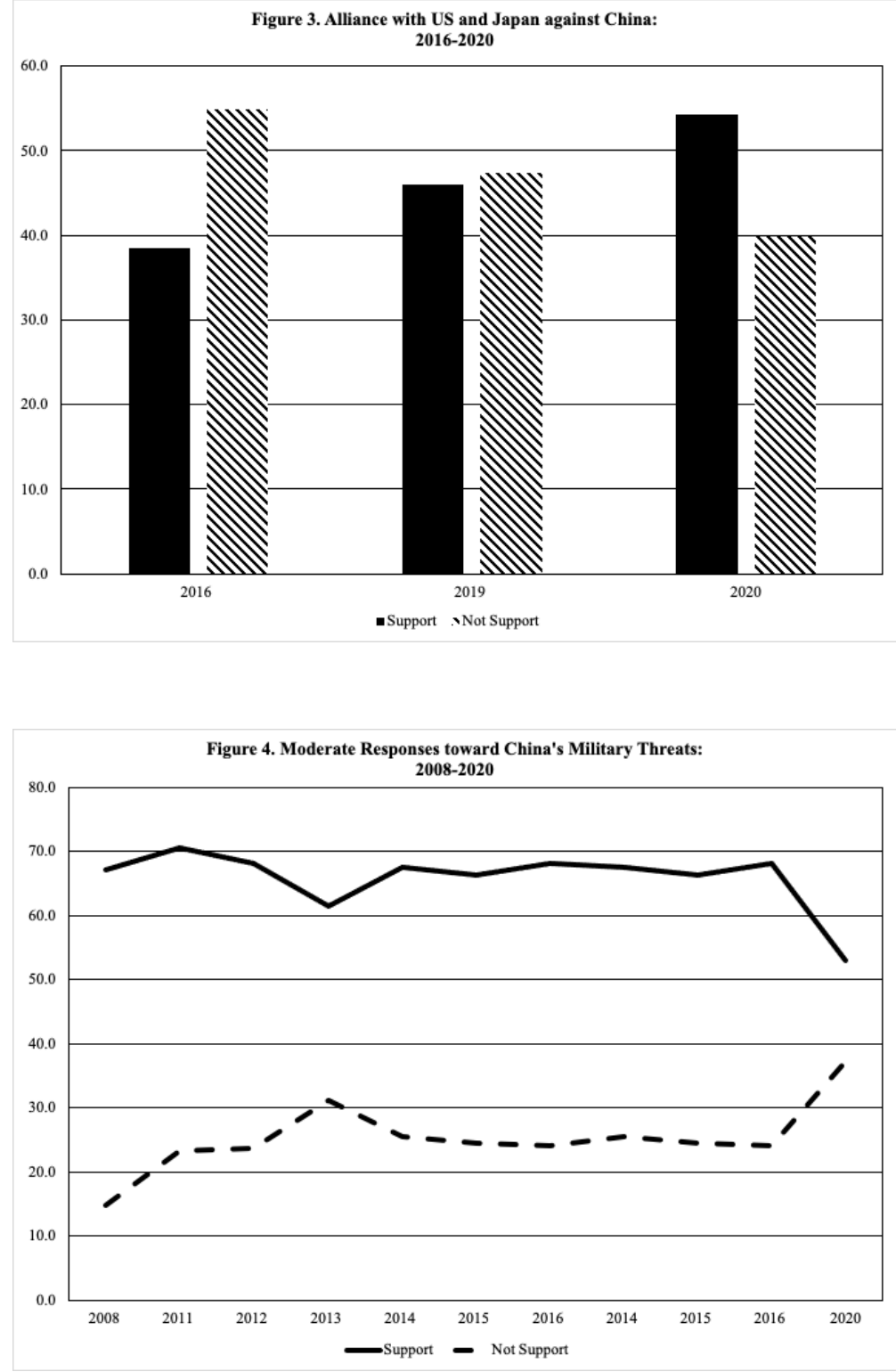

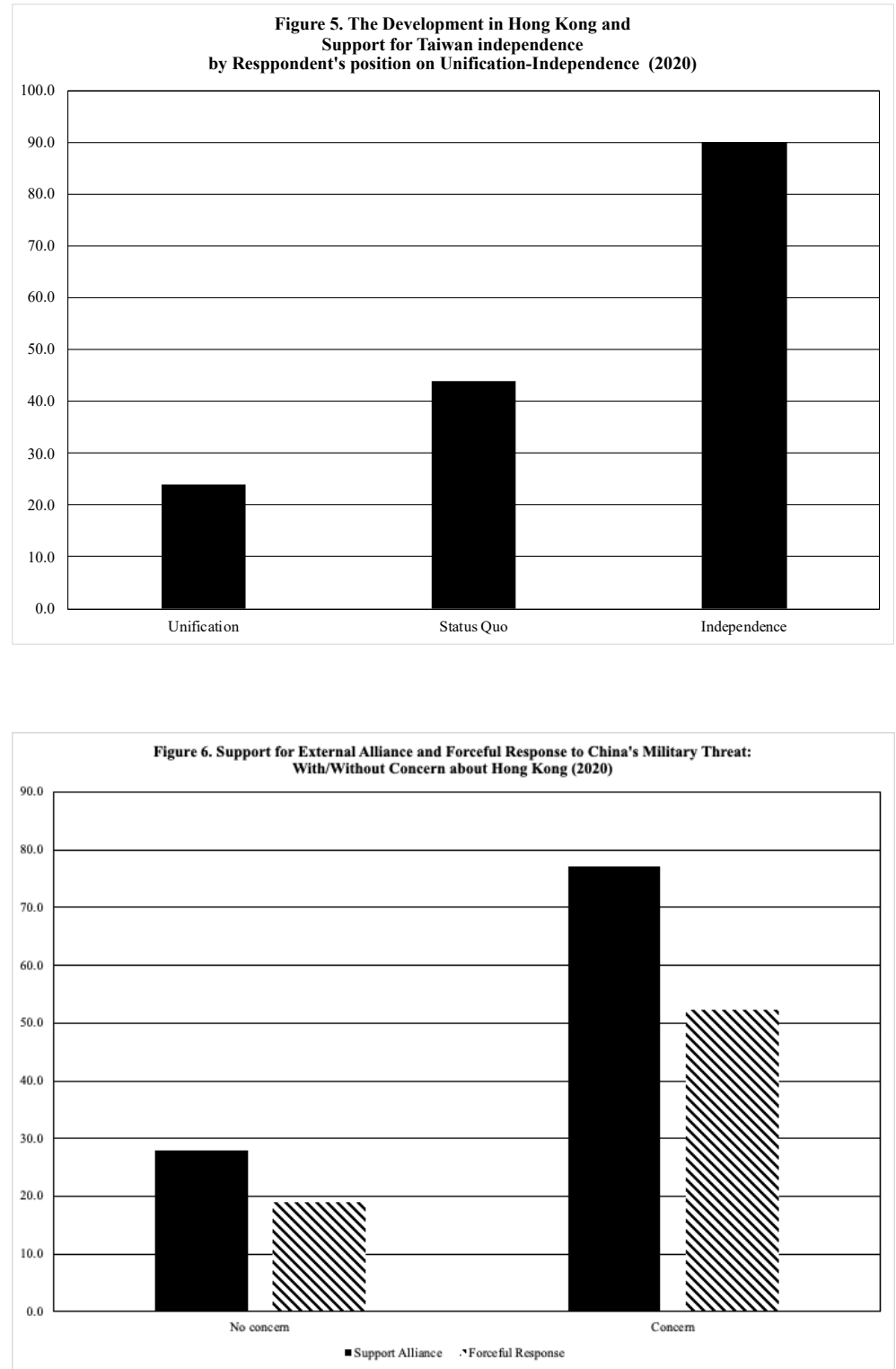

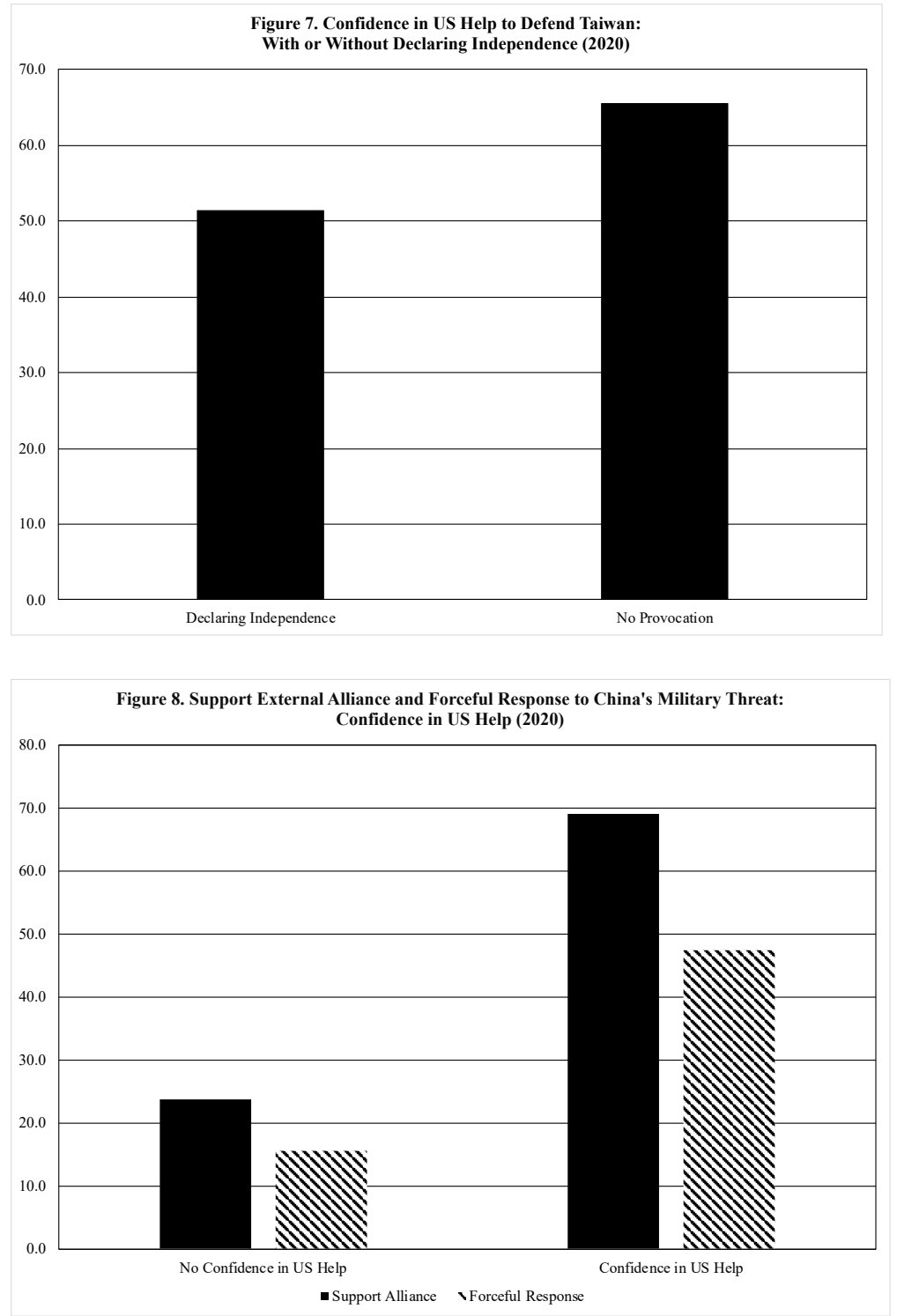

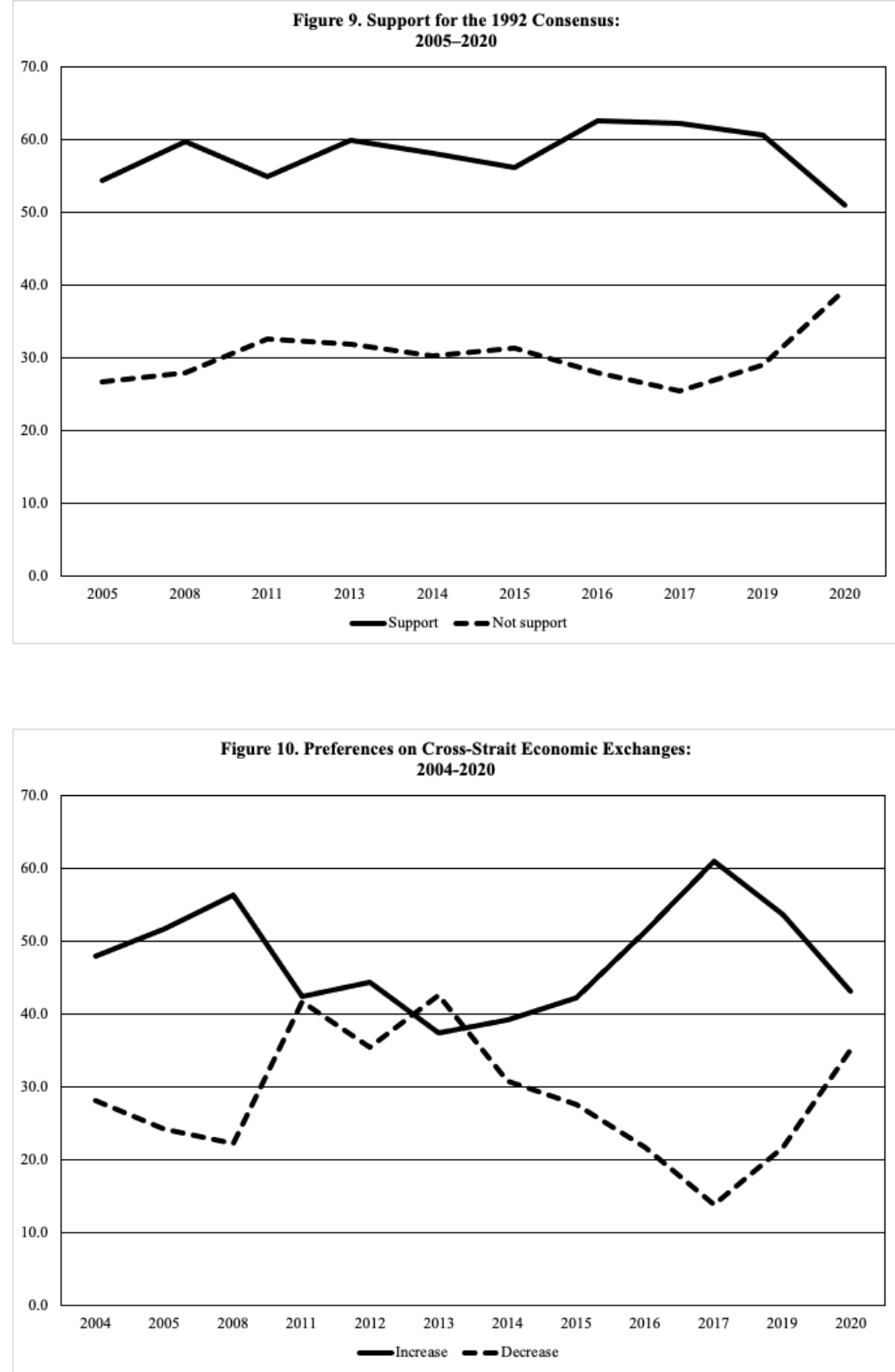


\section{References}

Almond, Gabriel A. 1950. The American People and Foreign Policy. New York: Harcourt, Brace.

Achen, Christopher and T.Y. Wang, eds. 2017. The Taiwan Voter. Ann Arbor: University of Michigan Press.

Basic Law of the Hong Kong Special Administrative Region of the People's Republic of China. 1990. https://www.fmprc.gov.cn/mfa_eng/lizg_665465/3566_665531/t23031.shtml. Accessed November 24, 2020.

Biden Jr., Joseph R. 2020. "Why America Must Lead Again: Rescuing U.S. Foreign Policy After Trump.” Foreign Affairs. v. 99, no. 2: 64-76.

Biden Jr., Joseph R. 2020. "Not So Deft on Taiwan.” The Washington Post. May 2. https://www.washingtonpost.com/archive/opinions/2001/05/02/not-so-deft-on-taiwan/2adf3075ee98-4e70-9be0-5459celedd5d/. Accessed 11/22/20.

Bosco, Joseph. 2020. "Where does Biden Stand on China and Taiwan?" The Hill. August 25. https://thehill.com/opinion/international/513392-where-does-biden-stand-on-china-and-taiwan. Accessed, November 22, 2020.

Brands, Hal and Jake Sullivan. 2020. "China Has Two Paths to Global Domination." Foreign Policy. May 22, https://foreignpolicy.com/2020/05/22/china-superpower-two-paths-globaldomination-cold-war/\#. Accessed November 27, 2020.

Brunnstrom, David and Michael Martina. 2021. "Biden sends unofficial delegation to Taiwan in 'personal signal'." Reuters. April 13, https://www.reuters.com/world/china/biden-sendsunofficial-delegation-taiwan-underscore-commitment-white-house-2021-04-13/. Accessed May $28,2021$.

Brunnstrom, David, Patricia Zengerle, Mike Stone. 2020. "White House moves forward on three arms sales to Taiwan: sources." Reuters. October 12, https://www.reuters.com/article/us-usataiwan-arms-exclusive/exclusive-white-house-moves-forward-on-three-arms-sales-to-taiwansourcesidUSKBN26X246?il=0. Accessed December 7, 2020.

Campbell, Kurt and Jake Sullivan. 2019. "Competition Without Catastrophe How America Can Both Challenge and Coexist With China." Foreign Affairs. September/October, https://www.foreignaffairs.com/articles/china/competition-with-china-without-catastrophe. Accessed November 28, 2020.

Chan, Steve. 2010. "An Odd Thing Happened on the Way to Balancing: East Asian States' Reactions to China's Rise." International Studies Review. v. 12, no. 3: 387-412.

Davidson, Helen. 2020. “Stronger together: Taiwan's foreign minister urges new alliance against 
China.” The Guardian. December 7 https://www.theguardian.com/world/2020/dec/07/strongertogether-taiwan-foreign-minister-urges-new-alliance-against-china; Accessed December 16, 2020.

Girard, Bonnie. 2020. "With New Offensive Weapons Package, Trump Administration Goes Allin for Taiwan." The Diplomat. October 30, https://thediplomat.com/2020/10/with-new-offensiveweaponspackage-trump-administration-goes-all-in-for-taiwan/. Accessed December 7, 2020.

Glaser, Bonnie, Scott Kennedy, Derek Mitchell with Matthew Funaiole. 2018. The New Southbound Policy: Deepening Taiwan's Regional Integration. Center for Strategic and International Studies. January 19, https://www.csis.org/analysis/new-southbound-policy. Accessed December 10, 2020.

Haass, Richard and David Sacks. 2020. "American Support for Taiwan Must Be Unambiguous." Foreign Affairs, September 2 https://www.foreignaffairs.com/articles/united-states/americansupport-taiwan-must-be-unambiguous; accessed April 15, 2021.

Ho, Karl, Cal Clark, and Alexander C. Tan. 2020. The New Southbound Policy. In Hans Stockton and Yao-yuan Yeh (eds.), Taiwan: The Development of an Asian Tiger. Boulder, Colorado, USA: Lynne Rienner: 133-148.

Horton, Chris Horton. 2019. "Faced With Tough Words From China, Taiwan Rallies Around Its Leader.” New York Times. January 19, https://www.nytimes.com/2019/01/19/world/asia/chinataiwan-president.html. Accessed November 15, 2019.

Hui, Victoria Tin-bor. 2017. "20 Years Ago, China Promised Hong Kong '1 Country, 2 Systems' So Much For Promises." The Washington Post. June 29, https://www.washingtonpost.com/news/monkey-cage/wp/2017/06/29/20-years-ago-chinapromised-a-1-country-2-systems-deal-for-hong-kong-that-wasnt-to-be/. Accessed August 23, 2019.

Jiang, Steven Chandelis Duster and Nicole Gaouette. 2020. "Chinese leader Xi Jinping Congratulates Biden on Winning Election." CNN. November 25. https://www.cnn.com/2020/11/25/politics/xi-jinping-joe-biden-congratulations/index.html. Accessed December 27, 2020.

Kang, David C. 2003/2004. "Hierarchy, Balancing, and Empirical Puzzles in Asian International Relations." International Security. v. 28, no. 3: 165-180.

Koga, Kei. 2018. "The Concept of "Hedging" Revisited: The Case of Japan's Foreign Policy Strategy in East Asia's Power Shift." International Studies Review. 20: 633-660.

Kuik, Cheng-Chwee. 2008. "The Essence of Hedging: Malaysia and Singapore's Response to a Rising China." Contemporary Southeast Asia. v. 30, no. 2: 159-85.

Kuo, Mercy. 2020. "Trump and the TAIPEI Act." The Diplomat. April 21, at 
https://thediplomat.com/2020/04/trump-and-the-taipei-act/. Accessed December 11, 2020.

Labs, Eric. 1992. “Do Weak States Bandwagon?” Security Studies, v.1, no.3: 383-416.

Lee, Matthew. 2020. "US approves armed MQ-9B drones purchase by Taiwan." Defense News. November 4, https://www.defensenews.com/unmanned/2020/11/04/us-approves-armed-mq-9bdrones-purchase-by-taiwan/; Accessed December 7, 2020.

Ma, Ying-jeou. 2008. "Taiwan's Renaissance.” Presidential Office of the Republic of China. www.president.gov.tw/en/. Accessed May 1, 2015.

Mainland Affairs Council (MAC). 2020. Monthly Report on Cross-Straits Economy (Liang-An Jingji Tong-ji Yue-Bao). No. 331. http://www.mac.gov.tw/. Accessed December 1, 2020.

Office of the President. 2019. "President Tsai issues statement on China's President Xi's "Message to Compatriots in Taiwan." The Republic of China, January 2. https://english.president.gov.tw/NEWS/5621. Accessed, January 5, 2019.

Pempel, T. J. 2010. "Soft Balancing, Hedging, and Institutional Darwinism: The EconomicSecurity Nexus and East Asian Regionalism." Journal of East Asian Studies. v. 10, no. 2: 209238.

Posen, Barry. 1984. The Sources of Military Doctrine: France, Britain, and Germany Between the World Wars. Ithaca: Cornell University Press.

Rigger, Shelley. 2009 "Needed: A Newish U.S. Policy for a Newish Taiwan Strait.” Foreign Policy Research Institute. http://www.fpri.org/enotes/200903.rigger.newishtaiwanstrait.html. Accessed April 1, 2009.

Roy, Dennis. 2005. "Southeast Asia and China: Balancing or Bandwagoning." Contemporary Southeast Asia. v. 27, no.2: 205-322.

Schroeder, Paul. 1994. "Historical Reality vs. Neo-Realist Theory." International Security, v. 19, no. 1: 108- 148.

Snyder, Glenn. 1984. "The Security Dilemma in Alliance Politics." World Politics. v.36, no. 4: $461-95$.

State Council of the PRC. 1993 "The Taiwan Question and Reunification of China." Beijing Review. 36:36 (September 6-12): i- viii,

Su, Chi, and Cheng An-guo, eds. 2002. Yige Zhongguo, Gezi Biaoshu' Gongshi de Shishi [One China, Different Interpretations: An Account of the Consensus]. Taipei: Guojia Zhengce Yanjiu Jijinhui.

Taiwan Affairs Office (TAO) and the Information Office of the State Council. 2000. "The One- 
China Principle and the Taiwan Issue." People's Daily (Renmin Ribao). February 21. http://www.peopledaily.com.cn. Accessed February 1, 2003.

Tan, Alexander C. 2012. "China and Its Neighbors: Too Close for Comfort?" In Kristen Williams, Steven Lobell, and Neal Jesse (eds.) Beyond Great Powers and Hegemons. Palo Alto: Stanford University Press.

Tan, Alexander C. and Karl Ho. 2017. “Cross-Straits Relations and the Taiwan Voter.” In Christopher Achen and T.Y. Wang (eds.) The Taiwan Voter. Ann Arbor: University of Michigan Press: 158-169.

Tan, Alexander C., Karl Ho, Cal Clark. 2020. "The Political Economy of Taiwan's Regional Relations." Asian Affairs: An American Review. v. 47, no. 3: 177-200.

Tan, Huileng. 2019. “Taiwan's president orders military to 'forcefully expel' future incursions of China warplanes." CNBC. April 2. https://www.cnbc.com/2019/04/02/taiwan-president-tsai-ingwen-on-china-warplanes-crossing-maritime-line.html. Accessed June 15, 2019.

Tsai, Ing-Wen. 2009. "CECA Comes With Big Hidden Costs." Taipei Times. March 1. http://www.taipeitimes.com/News/editorials/archives/2009/03/01/2003437304. Accessed April 1, 2009.

Walt, Stephen M. 1985. "Alliance Formation and the Balance of World Power.” International Security. v. 9, no. 4: 3-43.

Waltz, Kenneth. 1979. Theory of International Politics. New York: McGraw-Hill.

Wang, T.Y. 2017. "Changing Boundaries: The Development of Taiwan Voters' Identity." In The Taiwan Voter, edited by Christopher Achen and T.Y. Wang. Ann Arbor: University of Michigan Press: 45-70.

----. 2017. “Taiwan Citizens' Views on Cross-Strait Relations: Pragmatic but Ambivalent.” In T.J. Cheng and Wei-chin Lee (eds.) National Security, Public Opinion and Regime Asymmetry: A Six Country Study. New Jersey: World Scientific: 21-48.

Wang, T.Y., and I-chou Liu. 2004. "Contending Identities in Taiwan: Implications for CrossStrait Relations.” Asian Survey. V.44, no. 4: 568-90.

Williams, Kirsten, Steve Lobell, and Neal Jesse (eds). 2012. Beyond Great Powers and Hegemons. Palo Alto: Stanford University Press.

Wu, Linn, Mandy Yim, Wayne Chang and Jasper Cao. 2020. “Today's Hong Kong, tomorrow's Taiwan: Protesters find help and sympathy across the strait." Hong Kong Free Press, May 24. https://hongkongfp.com/2020/05/24/todays-hong-kong-tomorrows-taiwan-protesters-find-helpand-sympathy-across-the-strait/. Accessed June 30, 2020. 
Wu, Yu-Shan. 2017. "Pivot, Hedger, or Partner: Strategies of Lesser Powers Caught between Hegemons." In Lowell Dittmer, ed., Taiwan and China: Fitful Embrace. Berkeley: University of California Press: 197-220.

Xi, Jinping. 2019. "Highlights of Xi's speech at Taiwan Message Anniversary Event." China Daily. January 2. https://www.chinadaily.com.cn/a/201901/02/WS5c2c1ad2a310d91214052069.html. Accessed January 5, 2019. 